\title{
Fısıltı Gazetesinin Yönetimi: Kamu ve Özel Sektör Yöneticileri Arasında Karşılaştırmalı Bir Uygulama
}

\author{
Gökben BAYRAMOĞLU*
}

\begin{abstract}
$\ddot{O} Z$
Bilginin dedikodu ya da söylenti yoluyla kişiden kişiye informal yolla aktarılmasını sağlayan fisıltı gazetesi, dünyanın en eski medyası olarak kabul edilmektedir. Toplum bilimleri içerisinde önemli bir yer tutmasına rağmen örgütsel araştırmalarda ampirik olarak yeterince incelenmediği görülmektedir. Bu çalışmada, kurumlarda fisıltı gazetesinin nasıl çalıştığl ve kuruma etkilerinin neler olduğu araştırılmıştır. Bu kapsamda kamu ve özel sektörde faaliyet gösteren 315 yönetici ile anket çalışması yapılmıştır. Dedikodu genellikle eğlenme ve sohbet etmek amacıyla yapılır, ancak bazen de "daha iyi bir statü elde etmek" ve "başkalarının itibarını zedelemek" amacını taşımaktadır. Dedikodunun en olumsuz etkileri çalışanların moralinin bozulması, güven kaybı ve bunun sonucunda çalışanlar arasındaki uyumun azalmasıdır. Buna karşın yönetimin aldığ değişim kararlarına karşın kendini hazırlama olanağı sağlaması ve duygusal/psikolojik rahatlama sağlaması gibi olumlu sonuçlara da neden olabilmektedir.
\end{abstract}

Anahtar Kelimeler: Dedikodu, fisiltı gazetesi, sosyal örgüt, informal iletişim JEL Sınıflandırması: M10

\section{The Management of Grapevine: A Comparative Research Between Public and Private Sector Managers}

\begin{abstract}
Grapevine which allows information to be transmitted informally through gossip or rumor is accepted as the oldest media in the world. Although it has an important place in the social sciences, it is seen that it is not analyzed sufficiently empirically in organizational research. In this study, it was researched how the grapevine works in institutions and what is the effect on the institutions. Within this scope, a survey was conducted with 315 managers operating in public and private sectors. Gossip is usually aimed at having fun and chatting, but sometimes it is aimed at "getting a better status" and "damaging the reputation of others." The most negative impacts of the gossip are the deterioration of the morale of the employees, loss of confidence, and as a result decrease in cohesion among employees. In contrast with, it can also lead to positive results such as the ability to prepare himself/herself for the management decisions of change and emotional/psychological relaxation.
\end{abstract}

Key Words: Gossip, grapevine, social organization, informal communication

JEL Classification: $M 10$

\section{GíRiş}

Fısıltı gazetesi (FG) yaşamın içerisine yerleşmiş bir olgu olarak sosyoloji, antropoloji, psikoloji ve iletişim gibi birçok alanda incelenmesine rağmen örgütsel araştırmalar içerisinde çok fazla rağbet görmemesi oldukça ilginçtir. Yapılmış olan az sayıdaki çalışmalarda ise FG'ye dar bir bakış açısıyla yaklaşılmış ve genellikle olumsuz sonuçlar doğuran bir olgu olarak incelemiştir. 
Bu çalışmalarda, FG'nin çalışma biçimi olan dedikodu/söylenti süreçlerine katılan çalışanların gereksiz yere vakit kaybederek işgücü maliyetine neden oldukları ve FG'nin yöneticiler tarafından susturulması gereken bir yapı olduğu ifade edilmiştir. Ancak FG, olumsuz etkilerinin yanı sıra olumlu işlevlere de sahiptir.

$\mathrm{Bu}$ çalışmada "FG, ortadan kaldırılması gereken yıkıcı bir iletişim kanalıdır" ya da "FG, kurum içerisinde etkili bir iletişim kanalıdır" şeklinde kesin bir sonuca ulaşmaktan ziyade kurumlarda FG'nin detaylı bir şekilde incelenmesi amaçlanmıştır. Bu bağlamda FG'nin; yönetici/çalışanlara ve dolayısıyla kuruma etki ve sonuçlarına odaklanan daha geniş kapsamlı bir bakış açısıyla değerlendirilmesi hedeflenmiştir. Böylece çalışmanın literatürdeki eksikliğin giderilmesine katkıda bulunması beklenmektedir. Bu çalışma, üç temel önerme üzerine kurulmuştur. İlk olarak FG, ciddi bir inceleme ve analiz gerektiren bir konudur. İkincisi, kurumlarda FG yeterince incelenmemiştir. Üçüncüsü FG, işin insan boyutuyla ilgili önemli unsurların açıklanmasına yardımcı olan sosyal bir süreçtir. Bu üç önermeden hareketle, kurumlarda fisıltı gazetesinin nasıl çalıştığı, kurum açısından yarattığı sonuçlar ve yönetimine ilişkin geliştirilebilecek stratejilerin neler olabileceği araştırılmıştır.

\section{FISILTI GAZETESI}

FG, informal iletişim olarak tanımlanmakta olup sözlük anlamı itibariyle, "bilginin dedikodu ya da söylenti yoluyla kişiden kişiye informal yolla aktarlmasıdır" (Deepa ve Seth, 2016). FG, her kurumda yer alan informal ve doğrulanmamış bilgi ağı olup çalışanların çevresini anlamasına yardımcı olmaktadır (Mishra, 1990). FG'nin nasıl çalıştığını açıklamadan önce, dedikodu ve söylentilerin neden doğduğu, nasıl yayıldığ olacaktır. Dedikodu, "doğruluğuna ilişkin bir kanıt olmaksızın kişiden kişiye geçen bir bilgiye duyulan inançtır" (Rosnow, 1980). Ayrıca Elder ve Enke (1991:494) dedikoduyu "konuşmanın yapıldı̆̆ı esnada orada olmayan bir kişiyle ilgili olarak eleştirisel bir konuşma” olarak tanımlamaktadır. Söylentiyse TDK, tarafindan "ă̆ızdan ă̆ıza dolaşan, kesinlik kazanmayan haber, rivayet” olarak tanımlanmaktadir.

Dedikodu ve söylentilerin, yanlış bilgilerin yayılmasına neden olarak kuruma zarar verme potansiyeline rağmen örgütsel araştırmalarda yeterince incelenememesinin nedeni, araştırmacının dedikodu ortaya çıktıktan sonra konuya ilişkin olarak bilgi sahibi olabilmesidir. Araştırmacı, dedikoduyu öğrendiğinde dedikodu neredeyse son aşamasına ulaşmıştır. Bu nedenle araştırmacı, büyük olasılıkla içeriğinde bazı değişiklikler olmuş söylentinin anısı hakkında araştırma yapabilmektedir. Yani, araştırmacı söylentinin kendisini değiil; ancak kişiler üzerinde bıraktığı etkiyi araştırabilir (Manaf vd., 2013:51).

Dedikodu dört farklı şekilde gerçekleşir. Bunlardan ilki “hayal borusu” olup kişilerin umutlarını açıklamaktadır. Çalışanların işle ilgili değiştirilmesini istedikleri bir duruma ilişkin dedikodular gibi. İkincisi “öcü/kaygı" söylentileridir. Bunlar korkudan kaynaklanan ve kişilerde huzursuzluk yaratan dedikodulardır. İşletmenin satın alınacağına ve birçok kişinin işten çıkarılacağına ilişkin dedikodular örnek olarak verilebilir. Üçüncüsü yeni genel müdür gelip 
gelmeyeceğine dair dedikodular gibi "tahmin etme amaçlı" olup belirsizliğin arttı̆̆1 durumlarda ortaya çıkmaktadır. Başkalarına zarar verme niyetiyle yapılan “agresif" dedikoduysa grup uyumunun bozulmasına ve bölünmesine neden olabilir (Ribeiro ve Blakeley, 1995:44, Michelson ve Mouly, 2000:342).

Dedikodu ve söylenti birbirilerinin yerine kullanılabilmekle birlikte, aralarında farklılıklar vardır. Dedikodu; bilgi edinmek, başkalarını etkilemek ve sosyalleşmek amacı taşırken; söylenti, kişinin çevresini anlamasına yardımcı olan bilgilerin transfer edilmesidir (Dodig-Crnkovic ve Anokhina, 2008). Bu farklılıklar şu şekilde sıralanabilmektedir (Danış, 2015:11):

- Dedikodu belirli zaman ve mekâna aitken; söylenti zaman ve mekândan ayrışabilir ve başka zaman ya da mekânda yaşanmış gibi anlatılabilirler.

- Dedikoduda sosyalleşmek, muhabbet ya da eğlenmek amaçlanırken; söylentilerde spekülatif haberlerin (şehir efsanelerinin) yayılması amaçlanır.

- Dedikoduda ilk tanığa ulaşmak veya o kişiye atıfta bulunmak olanaklı iken söylentilerde ilk tanığa erişilemez.

- Dedikodu küçük bir grup içerisinde yapılır ve insanların dedikodusu yapılan kişiyle bir yakınlıkları vardır. Ancak söylentilere inanlar belirli bir zaman ve mekân içerisinde bulunmadıkları için belirli bir grup yoktur.

- Dedikoduda aktör ve temel mesaj değişmez ancak olayın kurgusu inandırıcılığı sağlamak amacıyla kısmen değişime uğrayabilir. Söylentilerdeyse aktör ve konu sürekli değişime uğrar.

\section{FISILTI GAZETESININ IŞLEVLERI}

Dedikodu genellikle kötü bir üne sahip olmakla birlikte birçok insan tarafindan siklıkla ve büyük bir keyifle yapılmaktadır (Beersma ve Kleef, 2011:642). Dedikodu, topluluğa bilmemesi gereken bir gerçeklik sunar. Bu nedenle, her birey dedikoduyu heyecanla bekler ve tanıdıklarına anlatmak ister. Bir sırrın kesintiye uğraması olan dedikodunun değeri sürekli olmadığı için, bilgiyi hızla yaymak gerekir. Dedikoduyu yayan kişi, önemli bir bilginin sahibi olarak diğerlerini aydınlatır ve bu aktarımdan yücelmiş olarak çıkar (Kapferer, 1992:21).

Dedikodular, çalışanların moralini bozarak verimliliğin düşmesine neden olabilir. Ancak potansiyel yararları da vardır (Michelson ve Mouly, 2002:58). Bu işlevleri sosyalleşme, grup dayanışmasını arttırma, davranış değişikliği sağlama, disiplin/sosyal kontrol ve bilgi sağlama olarak sıralamak olanaklıdır.

\section{A. Sosyalleşme}

"Sapiens: Insan Türünün Klsa Bir Tarihi” adlı eserinde Harari (2012:36), dedikodunun toplum içerisinde önemli işlevlere sahip olduğunu belirtmektedir. Homo Sapiens'in 30-70 bin yıl önce ortaya çıkan yeni iletişim biçimlerini açıklayan teorilerden biri, dilin dedikodu yapma aracı olarak evrimleştiği fikrinden hareket etmektedir. Homo sapiens sosyal bir canlı olduğu için; sosyal işbirliği, hayatta kalma açısından kritik bir önem taşımaktadır. Bu nedenle, yaşama ilişkin önemli bilgiler, vahşi hayvanlardan ziyade kabilede kimin kimden nefret ettiği, kimin kiminle ilişkisi olduğu ve kimin dürüst kimin hilebaz olduğuna ilişkin bilgilerdir. Aslına bakılırsa 50 kişiden oluşan bir grupta 1225 farklı birebir 
ilişki söz konusudur. Bu ilişkilerin yürütülebilmesi için dedikoduya gereksinim vardir.

Robin Dumbar da sohbetlerin 2/3'ünün sosyal konularla ilgili olduğunu ve dedikodunun tarih boyunca sosyal bağları güçlendirdiğini ifade etmektedir (Bhasin, 2013:18). Kim kimle ne yapıyor? Bu iyi bir şey mi yoksa kötü bir şey mi? Kim popüler? Sevgili, meslektaş ya da çocuklarla ilgili sorunlar gibi konular diyalogların temel konularıdır. Bazen $5 \mathrm{dk}$. farklı konular konuşulsa bile konuşma bir süre sonra tekrar hayatın normal akışına dönmektedir. Üniversitelerin ortak kullanım alanlarında ya da çokuluslu işletmelerin yemekhanesinde de durum çok farklı değildir. Zihin okumak gibi, sohbetlerden hangi anlamın çıkarılacağını bilmek de toplumsal varlığın temelini oluşturmaktadır. Buna göre; kim kiminle arkadaş? Kim daha dominant ve kimler izleyici? gibi belirsizlikleri anlayabilmek için kişiler arası yakınlıkların bilinmesi gerekir (Dunbar, 1997).

Dedikodular, gruba yeni katılanların oryantasyon sürecine de katk1 sağlamakta ve yeni gelenin, grup değerlerini ve normlarını içselleştirmesine yardımcı olmaktadır. FG, mesajı yeni gelenin örgütün değerlerini, uygulamalarını ve rol beklentilerini anlamasını sağlayacak şekilde dönüştürür. Ancak kimi zaman bu süreç, istenmeyen uygulamaları ve değerleri değiştirmek isteyen inovatif yöneticiler için ekstra sorunlara neden olabilmektedir (Ribeiro ve Blakeley, 1995).

\section{B. Grup Dayanışmasını Artırma}

Antropolojiden gelen işlevci görüş dedikoduyu, grup dayanışmasını güçlendiren ve toplumsal değerlerin iletilmesini sağlayan normatif kurallara dayanan eleştiri biçimi olarak kabul etmektedir (Hallett vd., 2009:587). Dedikodu sayesinde elde edilen "kime güvenilebileceğine dair bilgi" küçük grupların, daha büyük gruplara dönüşmesine ve daha karmaşı işbirliği yöntemlerinin geliştirilmesine yardımc1 olmuştur (Harari, 2012:36). Kişi, dedikodu aracılığıyla geçmişteki davranışlarına ilişkin bilgi sahibi olduğu kişilerle partner olup olmama kararını daha doğru verebilmekte ve işbirliği kolaylaşmaktadır. Ayrıca dedikodu grup içerisinde normatif kurallara uymayanları belirlemeye ve damgalamaya olanak sağlamakta ve bu şekilde sömürücü davranışların ortadan kaldırılmasına yardımcı olmaktadır. Standford Üniversitesinde Feinber, Willer ve Schultz (2014) da dedikodunun işbirliğini arttırıcı etkisine vurgu yapmış ve sosyalleşme aracı olarak işlev gören dedikodunun engellenmesinin asosyalliğe neden olacağını ifade etmişlerdir.

\section{Davranış Değişikliği Sağlama}

Dedikodu, bir grup ya da kültürde yaşamak için gerekli kurallar, normlar ve yönergelere ilişkin bilgileri aktarmanın etkili bir aracıdır (Beersma ve Kleef, 2011). Aslında bir hikâye anlatma biçimi olan dedikodu, topluluğun üyelerine kim oldukları, neye inanmaları gerektiği ve neyi yapması gerektiğini anlatmaktadır (Danış, 2015). Eğer bir kişi, grubun üyesi olarak kalmak istiyorsa hangi konuda ne düşünmesi gerektiğini grup ona dedikodu yoluyla iletir. Dedikodu, toplumsal kaynaşmanın bir aracıdır. Yapılan bütün tartışmalar, kendisini özdeştirdiği grubun görüşlerini yansıtmaktadır. Sonuç itibariyle 
dedikoduya katılma aynı zamanda bir gruba katılma eylemidir (Kapferer, 1992:69). Kısaca ifade etmek gerekirse dedikodu; toplumsal dünyayı anlamak ve etkili bir önlem alabilmek için kolektif sezme kabiliyetidir. Bu şekilde gerçekleşen bir iletişim, belirsizliği azaltarak öncelikle insanların olayları anlamlandırmasına ve riski yönetmesine yardımcı olmaktadır (DiFonzo vd, 2013:379).

\section{Disiplin/Sosyal Kontrol}

Bir karınca kolonisi gibi işbirliği içerisinde ve özgeci davranmaya zorlanan insan için; hileci ve kaytarıcıları saptamak için dedikodu gereklidir (Kanber, 2015:7). Dedikodu, grup normlarını ihlal edenlerin saptanmasını sağlar (Noon ve Delbridge, 1993) ve bu normları ihlal etmenin sonuçlarını gösterir (Dingfelder, 2006). Dedikodunun en popüler konularını, ihanet, hile, saldırganlık, cinsellik, sosyal statü, doğum/ölümler, siyasi/dini taahhütler, fiziksel ve psikolojik sağlık gibi insan ilişkileri oluşturmakta (Dodig-Crnkovic ve Anokhina, 2008) ve ne kadar skandal özelliği taşırsa o kadar hızlı yayılmaktadır (Noon ve Delbridge, 1993:30).

$\mathrm{Bu}$ açıdan, grup üyelerini istismar edenlerin bu sömürünün doğrudan gözlemlenemediği durumlarda bile izlenmesine yardımcı olan bir polislik görevi görmektir (Feinberg, Willer ve Schultz, 2014). Yani dedikodu, bir sosyal yaptırım olarak kavramsallaşmakta (Beersma ve Kleef, 2011:643) ve hem araçları hem de sonuçları düzenlemektedir (Noon ve Delbridge, 1993:28).

Kurumlardaysa yöneticilerin emirlerinin, çalışanlar tarafindan her zaman tam olarak yerine getirilmediği görülmektedir. Özellikle çalışanların, yöneticilerin huzurundayken kendilerini ifade biçimleriyle, yöneticinin olmadığı durumlar arasında çok önemli farklar bulunmaktadır. FG, bu sapmayı daha iyi tespit etmekte ve resmi disiplin süreçlerine başvurmaksızın davranışın düzeltilmesine olanak sağlamaktadır. Böylece, çalışanların grubun çalışma normlarına uymasına ve daha iyi performans göstermesine yardımcı olabilir (Nicoll, 1994:26).

\section{E. Bilgi Edinme ve Belirsizliği Azaltma}

Kurumlarda neredeyse tüm kararlar çalışanların bilgisi dışında alınmakta ve kişiler ancak karar alındıktan sonra durumdan haberdar olabilmektedir. İnsanlar, gelecekleri üzerindeki denetimi kaybettikleri duygusuna kapıldıkları zaman dedikodu yapmaya başlar (Kapferer, 1992:232). Dedikodu, kişilerin bilgi toplamasına, değerlendirmeleri paylaşmasına, koşulları anlamasına ve kendini hazırlamasına olanak sağlamakta ve böylece belirsizlik hissini azaltmaktadır. Ancak aynı zamanda kurumda tam tersi olarak endişeyi ve gerginliği arttırabileceği de unutulmamalıdır (Dodig-Crnkovic ve Anokhina, 2008).

\section{III. İŞYERINNDE FISILTI GAZETESI NASIL ÇALIŞIR?}

Kurumlar büyük bir gizlilik mekanizması olduğu için dedikodu üretimi için oldukça elverişlidir. Fabrikanın kapanması, işten çıkarma, fabrikanın merkezini değiştirme, terfi vb. dönemler daha yükssek potansiyel taşır. Gerilim ve stresin yoğun olması da dedikodu üretme olasılığının arttırmaktadır. Sürekli çıkar çatışmalarının yaşandığı kurumlarda dedikodular; hiyerarşik ilişkileri, işçi-patron ilişkilerinin ve bireyler arasındaki uyuşmazlığın dokusunu yansıtır (Kapferer, 
1992:232). Buna karşın dedikodu, bürokratik yapıları hümanize ederek "hayatta kalma mekanizması" sağlar ve çalışanların stres düzeylerini azaltabilir (Michelson ve Mouly, 2000:342).

Keith Davis (1969), FG'nin sağlıklı insan iletişiminin bir ifadesi olduğunu ve çalışanların işleriyle ilgili konuşmamasının aslında işlerine uyum sağlayamadıklarının bir göstergesi olabileceğini ifade etmektedir. Her şeyden önce bir iletişim ağ olarak değerlendirilmesi gereken FG, sosyal etkileşimlerden doğan kararsız, dinamik ve tıpkı insanlar gibi farklı yapılara sahiptir. Bu yap1, insanların konuşma özgürlügünün kullanması olarak kabul edilmesi gereken doğal ve normal bir etkinliktir. FG; serviste, koridorlarda, toplantılarda, kahve makinesinin başında ve yönetimin konuşulan konular üzerinde kontrolünün kısıtlı olduğu öğle aralarında yani neredeyse tüm gün boyunca çalışır. Mesai bitse de insanlar işten sonra kafe vb. bir yerde toplandığında kalınan yerden devam edilir. Ertesi gün döngü yeniden tekrar etmektedir (Mishra, 1990:222).

$\mathrm{Bu}$ yapı içerisinde bilgilerin dedikodu potansiyeli Dedikodu= önem $\mathrm{X}$ belirsizlik denklemi ile belirlenir (Mishra, 1990): Önem sıfirsa ya da belirsizlik söz konusu değilse dedikodu ortaya çıkmaz. Çalışanların anlamak isteyip de resmi olarak bir cevapla ikna edilmedikleri her durumda dedikodu ortaya çıkacaktır. Bu açıdan değerlendirildiğinde dedikodu, bilginin karaborsasıdır (Kapferer, 1992:19). Diğer bir deyişle kurumun resmi hiyerarşik yapıları ve iletişim kanalları, çalkantılı ve hızlı bir hale gelen iş çevresiyle yeterince baş edemediği ve resmi ağların problemleri çözme konusunda yetersiz kaldığı dönemlerde FG çok güçlü bir şekilde ortaya çıkacaktır. Çünkü çalışanlar, her şeyi bilmelerinin olanaklı olmadığının farkındadır. $\mathrm{Bu}$ nedenle işin gerektiği çok özel becerileri gerçekleştirebilmek için başkalarına güvenmek zorunda olduklarını bilirler. Çalışanlar arasında networkün gelişmesiyle, güçlü ve büyük bir FG ortaya çıkmaktadır (Nicoll, 1994:25).

Dedikodunun yayılması dört aşamada gerçekleşmektedir. Dedikodunun üretildiği ilk aşamada güven eksikliği ve tansiyon kilit bir önem taşımaktadır. İkinci aşamada farklı insanlar dedikoduya duyarlı hale gelir ve bireysel karakterlerine ya da öznel deneyimlerine göre tepki verirler. Bazıları daha ilgili ve meraklı olup dedikoduyu diğerlerine aktarma konusunda daha istekli olurlar. Üçüncü aşamada insanlar dedikoduyu anlatan kişinin karakterini ve güvenirliliğini kendi kriterlerine göre değerlendirmeye başlarlar (Gholipout vd., 2011). Ancak dedikodu, insanlara güvendiği kişiler aracıllğıyla ulaştığı ve toplumsal hayat da güven üzerine kurulu olduğu için, tanıdığı tarafindan kandırmayacağına inanan kişi tarafindan haber doğrulanması yapılmış kabul edilir ve dedikoduyu yaymaya başlar (Kapferer, 1992:24). Dedikodunun yayılması son aşaması olup sürekli tekrar ettirilmektir.

Normal koşullarda FG'den gelen bilginin \%80'ni doğrudur. Ancak yanlış olması halinde dramatik sonuçlara neden olduğu için insanlar genellikle olumsuz sonuçları hatırlar (Davis, 1973:55). Dedikodu, detaylarla ilgili bir dirençle karşılaştığı takdirde yeniden yapılandırılabilecek şekilde esnektir. Dedikoduyu yayan kişi, genellikle mesaja tam olarak sadık kalmaya çalışmaz ve karşısındakini 
ikna etmek için mesajı düzeltmeye istekli olur. Ayrıca mesaj basitleştirilerek ayrıntılara girilmediği için yanlış yorumlamalara neden olabilmektedir. (Manaf vd., 2013:53). Özetle, FG'de dolaşan bilginin büyük çoğunluğu doğrudur ancak \%100 doğru olan bilgilerin sayısı nispeten azdır (Deepa ve Seth, 2016:4).

FG'nin iletişim zinciri oldukça esnek olup dört farklı yapı baskındır (Davis, 1953:219):

- Tek telli zincir: Basit bir yapıdır. A, B'ye; B'se C'ye söyler. Her bir kişi bilgiyi kendisinden sonraki kişiye aktarır. Zincir uzadıkça deformasyon artar ve bilginin içeriğinde önemli değişiklikler olur. En önemli yanlışliklar bu zincirde görülür.

- Dedikodu zinciri: A iletişimde olduğu herkese bilgiyi aktarır ancak bilgi yayılması yavaştır.

- Olasslık zinciri: $\mathrm{Bu}$ durumda $\mathrm{A}$ tesadüfen $\mathrm{F}$ ve $\mathrm{C}$ ile kontak kurar ve bilgiyi aktarır. Onlarda olasılık yasalarına uygun olarak rastgele başkaları ile kontak kurarlar. Kimileri bu bilgileri duyar kimileri duymaz. Bu yapida kesin bir iletişim modeli yoktur. Bilgiler dinlemek isteyen herkese iletilir. $\mathrm{Bu}$ şekilde iletişim kuran kişiler; genellikle girişken ve konuşkan bireylerdir.

- Kümelenmiş zincir: Burada A kontak halinde olduğu B ve C'ye söyler. Onlarda kendileriyle kontak halinde olan kişilere söylerler. En baskın olan örnek kümelenme zinciridir. Seçicilik burada esastır. Her kurumda bireyler, bazı kişilerle iletişim kurmada kendilerini daha rahat hissederler. Bu yüzden de bu tür informal bilgileri paylaşma açısından onlara güvenirler. $\mathrm{Bu}$ akış, bazı insanların bu haberleri tamamen kaçırmasına neden olmaktadır.

\section{FISILTI GAZETESININ YÖNETIMI}

Yöneticiler genellikle resmi iletişim araçlarını tercih ederken; çalışanlar öncelikle FG'ye güvenmektedir (Baker ve Jones, 1996:76). FG çok kısa sürede örgüt içerisinde aşağı, yukarı, yatay ya da çapraz hareket edebilme yeteneğine sahiptir (Deepa ve Seth, 2016:2). İnsanlar, dedikoduyu tanıdık kişilerle yapmayı tercih ettiklerinden dolayı FG, en sert güvenlik duvarlarını bile aşabilir ve ayrıca yazılı bir kanıt olmadığı için hatalardan da sorumlu tutulamaz (Rivero, 2013:52). $\mathrm{Bu}$ nedenle yöneticiler, genellikle bu gazeteyi susturmak istemektedir. Ancak, bu genellikle işe yaramayan bir stratejidir. Çünkü FG; kaldırılıp atılamaz, halı altına süpürülemez, bağlanamaz ya da durdurulamaz. Bir yerde bastırıldığında, başka bir yerden yeniden ortaya çıkar ya da kaynaklarından biri kesildiğinde başka bir kaynaktan beslenmeye başlar. Bir bakıma FG, insanların doğal bir hakkı olup ne zaman bir grup insan bir araya gelse kaçınılmaz olarak ortaya çıkmaktadır (Davis, 1973:53).

Eğer dikkatli bir şekilde yönetilirse; yönetici ya da kurumun iletişim sorumlusu FG'yi "örgütsel hedeflerin başarılmasını kolaylaştırmak için çalışma ortamında kararlılık ve güvenirlilik sağlamak” için kullanabilir. Başka bir deyişle, kurum kültürü ve iletişim felsefesinden ciddi olarak endişe duyulduğu dönemlerde özellikle FG'nin göz ardı edilmemesi gerekmektedir. Zira bu kanal kurumun temelinde yatan kültürü ve değerleri en çok yansıtan kanaldır (Nicoll, 1994:25). 


\section{YÖNTEM}

\section{A. Araştırmanın Amacı}

Bu çalışmada, kurumlarda FG'nin çalışma biçimini ve kuruma etkilerinin detaylı bir şekilde analiz edilmesi ve etkili yönetim stratejilerinin neler olabileceğini araştırılması amaçlanmıştır.

\section{B. Araştırmanın Önemi}

FG, gerek gündelik yaşamda gerekse iş hayatında faaliyetleri hiç durdurmayan bir iletişim kanalı olarak toplumsal araştırmalar içerisinde kendisine geniş bir yer bulurken; örgütsel araştırmalarda yeterince ilgi görmemesi ya da konuya sadece negatif bir bakış açısıyla yaklaşılması literatürde eksikliğe neden olmaktadır. Ayrıca konunun her boyutu ile incelenmemiş olması; yöneticilerin konunun önemini yeterince kavramalarına olanak sağlayacak bir teorik birikimin oluşmasına engel olmaktadır. Bunun en önemli sonucu ise yöneticilerin, FG ile ilgili stratejilerinin daha çok "FG'yi bastırma/yok etme" şeklinde ifade edilebilecek ve başarı ihtimali oldukça düşük olan geleneksel yöntemlerden oluşmasına neden olmaktadır. Bu açıdan çalışmanın, yöneticilere daha geniş bir perspektif sağlaması beklenmektedir.

\section{Araştırma Yöntemi}

$\mathrm{Bu}$ çalışmada keşifsel analiz yöntemi benimsenmiş olup herhangi bir hipotez test edilmemiştir. Çalışmanın seyrini düzenlemek için aşağıdaki araştırma soruları belirlenmiştir:

- Yöneticiler, kurumlarında ne sıklıkla dedikodu ya da söylentiler duymaktadır?

- Yöneticiler, daha çok hangi konularda dedikodu yapıldığını düşünmektedir?

- Yöneticiler dedikodunun hangi olumsuz etkileri olduğunu düşünmektedir?

- Yöneticiler dedikodunun ne gibi olumlu etkileri olduğunu düşünmektedir?

- Kamu ve özel sektör yöneticilerinin dedikoduya bakış açıları açısından görüş farklılıkları var midır?

Veri toplama yöntemi olarak da anket tekniği kullanılmıştır. FG'nin olumsuz imajı nedeniyle, katılımcıların görüşlerinin tam olarak alınabilmesi için Likert ölçeği ile hazırlanmış ölçeğin yanı sıra çoktan seçmeli sorular sorulmasının yararlı olacağı düşünülmüştür. $\mathrm{Bu}$ nedenle anketin oluşturulmasında öncelikle Hitit Üniversitesinde görev yapan ve uzmanlık alanı davranış bilimleri olan akademisyenlerin, dedikodunun toplumsal boyutları ile ilgili görüşleri alınmış ve elde edilen bilgilerle birlikte literatürde daha önce yapılan çalışmaların (DiFonzo ve Bordia, 2000; Mishra, 1990) sonuçları dikkate alınarak çoktan seçmeli sorular hazırlanmıştır. Araştırmanın 5'li Likert ölçeği ile hazırlanmış bölümünde Deepa ve Seth (2016) tarafından hazırlanan ve geçerliliği ve güvenirliliği tespit edilmiş ölçekten yararlanılmıştır.

Araştırma kamu ve özel sektörde görev yapan 315 yönetici ile yapılan anket çalışmasından oluşmaktadır. Yöneticilerin zaman ve iş yoğunluklarının fazla olmasından dolayı, kolayda örneklem yöntemi tercih edilmiştir.

\section{Araştırma Bulguları}

Araştırma bulguları; demografik faktörler, fisıltı gazetesinin çalışma biçimi daha sonra da örgütsel iletişim açısından detaylı olarak incelenmiştir. 


\section{A. Demografik Faktörler}

Katılımcıların demografik özellikleri ve çalıştıkları kurumlara ilişkin bilgiler Tablo-1'de verilmiștir.

Tablo 1: Katılımcıların Demografik Özellikleri

\begin{tabular}{|c|c|c|c|c|c|}
\hline Yaş & Sıklık & Yüzde & \begin{tabular}{|l} 
Faaliyet alanı \\
\end{tabular} & Sıklık & Yüzde \\
\hline $21-25$ & 27 & 8,6 & İmalat & 34 & 10,8 \\
\hline $26-30$ & 50 & 15,9 & Ticaret & 91 & 28,9 \\
\hline $31-35$ & 60 & 19 & Hizmet & 74 & 23,5 \\
\hline $36-40$ & 63 & 20 & Kamu & 116 & 36,8 \\
\hline $41-45$ & 60 & 19 & Cinsiyet & Siklık & Yüzde \\
\hline $46-50$ & 31 & 9,8 & Kadın & 106 & 33,7 \\
\hline 51 ve üzeri & 24 & 7,6 & Erkek & 209 & 66,3 \\
\hline Deneyim süresi & Sıklık & Yüzde & İşyeri deneyim & Sıklık & Yüzde \\
\hline 1 yıldan az & 16 & 5,1 & 1 yildan az & 37 & 11,7 \\
\hline $1-3$ y1l & 29 & 9,2 & $1-3$ yıl & 62 & 19,7 \\
\hline $4-6$ y1l & 39 & 12,4 & $4-6$ y1l & 61 & 19,4 \\
\hline $6-9$ y1l & 64 & 20,3 & 6-9 yil & 72 & 22,9 \\
\hline $10-15$ y1l & 73 & 23,2 & $10-15$ y1l & 50 & 15,9 \\
\hline $16-20 \mathrm{y} 1 \mathrm{l}$ & 34 & 10,8 & $16-20 \mathrm{y} 1 \mathrm{l}$ & 16 & 5,1 \\
\hline $21-25 \mathrm{y} 1 \mathrm{l}$ & 30 & 9,5 & 21-25 y1l & 9 & 2,9 \\
\hline 25 y1ldan fazla & 30 & 9,5 & \multirow[t]{6}{*}{25 yıldan fazla } & \multirow[t]{6}{*}{8} & \multirow[t]{6}{*}{2,5} \\
\hline Çalıșan Sayısı & Sıklık & Yüzde & & & \\
\hline 9 kişiden az & 120 & 38,1 & & & \\
\hline 9-49 kişi & 97 & 30,8 & & & \\
\hline $50-149$ & 64 & 20,3 & & & \\
\hline 150 ve üzeri & 34 & 10,8 & & & \\
\hline
\end{tabular}

Tablo-1 incelendiğinde katılımc1ların 36-40 (\%20) ve 40-45 (\%19) yaş grubunda olanların daha baskın olduğu görülmektedir. Özel sektörde faaliyet gösteren katılımcıların sayısı 199 iken 116'sı çeşitli kamu kurumlarında yöneticilik yapmaktadır. Ayrıca katılımcıların büyük bir çoğunluğu erkeklerden oluşmaktadır $(\% 66,3)$.

\section{B. Fısıltı Gazetesinin Çalış̧ma Biçimi}

Katılımcılara hangi sıklıkla dedikodu ya da söylenti duydukları sorulmuş ve yanıtlar Tablo-2'de verilmiştir.

Tablo 2: Dedikodu Duyma Sıklığı

\begin{tabular}{lcc}
\hline Dedikodu duyma sıklı̆̆ & Sıklık & Yüzde \\
\hline Neredeyse her gün & 90 & 28,6 \\
Haftada bir & 67 & 21,3 \\
Ayda bir & 74 & 23,5 \\
6 ay ve üzeri & 84 & 26,7 \\
Toplam & 315 & 100,0 \\
\hline \hline
\end{tabular}

Katılımcıların \%27'si 6 aydan fazla süreyle dedikodu duymadıklarını; buna karşın yaklaşık \%29'u neredeyse her gün dedikodu duyduklarını beyan etmişlerdir. Haftada bir ve ayda bir diyenlerin oranları da nispeten yüksektir. Bu durum FG, sürekli çalışan bir iletişim kanalı olduğu bilgisini desteklemektedir. Yöneticiler ve çalışanlar, kanaldan neredeyse her gün yeni bir bilgi almaktadır. 
Ancak kanaldan bilgi gelmesi, bu bilgilere inanılacağı anlamına gelmemektedir. Bu nedenle katılımcılara, dedikodu ile ilgili çeşitli yargılar sunulmuş ve içlerinden kendileri için en uygun olanı seçmeleri istenmiştir (Tablo-3).

Tablo 3: Dedikoduya İlişkin Yargılar

\begin{tabular}{lcc}
\hline Dedikodu & Siklık & Yüzde \\
\hline Dedikodu her zaman yanlış bilgilerin yayılmasına neden olur & 79 & 25,1 \\
Dedikodular, abartılmış bile olsa doğruluk payı yüksek olan bilgilerdir & 79 & 25,1 \\
Dedikodunun doğruluğu, söyleyen kişinin güvenirliliğine bağlıdır & 82 & 26,0 \\
Dedikodunun doğruluğu, söyleyen kişinin niyeti ile yakından ilgidir & 75 & 23,8 \\
Toplam & 315 & 100,0 \\
\hline \hline
\end{tabular}

Tablo-3'te görüleceği üzere katılımcıların 1/4’ü dedikoduların her zaman yanlış bilgilerin yayılmasına neden olduğuna inanmaktadır. Diğer katılımcıların ise, dedikoduyu öğrendikleri kişinin güvenirliliğine ve niyetine bağlı olarak doğru olabileceğine ilişkin bir algıya sahip olduğu ifade edilebilmektedir. Katılımcıların $\% 25$ 'i ise dedikoduları doğruluk payı yüksek bilgiler olarak değerlendirmektedir. Teorik kısımda da vurgulandığı üzere toplumsal hayat güven üzerine kuruludur. İnsanlar güvendikleri kişilerden elde ettikleri bilgileri sorgulamaksızın kabul etmektedir. $\mathrm{Bu}$ bilgiyle tutarlı olarak katılımcıların \%26's1, dedikoduyu duydukları kişileri güvenilir olarak tanımladıklarında, elde edilen bilgiyi de doğru kabul etmeye meyilli oldukları görülmektedir. Araştırma kapsamında öncelikle yöneticilere, çalışanların neden dedikodu yaptığını düşündükleri sorulmuş ve yanıtlar Tablo-4'te verilmiştir. Bu sorularda katılımcılar birden fazla seçenek tercih edebilmektedir.

Tablo 4: Dedikodu Yapma Nedenleri

\begin{tabular}{lll}
\hline & Özel & Kamu \\
\hline Merak duygusunu tatmin etmek & $\mathbf{3 5 \%}$ & $\mathbf{4 9 \%}$ \\
Sohbet ve eğlenme & $\mathbf{4 1 \%}$ & $\mathbf{3 4 \%}$ \\
Başkalarının itibarını ya da saygınlığını azaltma & $26 \%$ & $\mathbf{3 6 \%}$ \\
Daha yüksek güç ve statü elde etme & $\mathbf{3 2 \%}$ & $18 \%$ \\
Başkalarının davranışlarını kontrol etme & $30 \%$ & $27 \%$ \\
Sosyalleşmek & $24 \%$ & $27 \%$ \\
Değişikliklerin yarattığı belirsizlik korkusu ile mücadele etme & $15 \%$ & $19 \%$ \\
& $221 \%$ & $22 \%$ \\
\hline \hline
\end{tabular}

Tablo-4'te de görüleceği üzere özel sektörde "sohbet/ eğlenme", "merak duygusunu tatmin etme" ve "daha yüksek güç ve statü elde etmek" amaciyla dedikodu yapılması daha yaygındır. Buna karşın kamuda "merak duygusunu tatmin etmek", "başkalarının itibarını ya da saygınlığını azaltma" ve "sohbet ve eğlenme" amacıyla dedikodu yapılmaktadır. Agresif dedikodu olarak tanımlanan "daha yüksek güç ve statü elde etmek" ya da "itibarsızlaştırma" amaçlı dedikodular, grup uyumunu bozan ve kuruma en çok zarar veren dedikodulardır. Her iki grupta da hatırı sayılır bir düzeyde agresif dedikodu olduğu gözlemlenmektedir. Yöneticilere hangi konularda dedikodu yapıldığı sorulmuştur (Tablo-5). 
Tablo 5: Dedikodu Olma Potansiyeli Taşıyan Konular

\begin{tabular}{lcc}
\hline & Özel & Kamu \\
\hline İş ortamı & $\mathbf{\% 4 3}$ & $\mathbf{\% 6}$ \\
İş tatmini & $\mathbf{\% 2 8}$ & $\% 9$ \\
Grup norm ve değerlerine aykırı davrananlar & $\% 11$ & $\% \mathbf{2 7}$ \\
Kurum içerisindeki kişilerin özel yaşamı & $\% 12$ & $\% 31$ \\
Ücret vb. maddi konular & $\% 39$ & $\% \mathbf{4 5}$ \\
Yatırım değişikliği & $\% 5$ & $\% 5$ \\
Kurumun mali durumu & $\% 17$ & $\% 7$ \\
Satın alma/_birleşme & $\% 8$ & $\% 2$ \\
İşten çıkarma & $\% 22$ & $\% 19$ \\
Yönetim değişikliği & $\% 6$ & $\% 19$ \\
Kriz dönemleri & $\% 13$ & $\% 11$ \\
\hline \hline
\end{tabular}

Tablo-5'den görüleceği üzere her iki grupta da dedikoduların temel konusunu "iş ortamı" ve "ücret vb. maddi konular" oluşturmaktadır. İş hayatı ve ücret vb. maddi konular, bireylerin gündelik yaşamını ve yaşam kalitesini etkileyen önemli unsurların başında geldiği için oldukça doğaldır. Ancak kurumun mali durumu, satın alma/birleşmeler ya da yatırım değişiklikleri bireyleri çok fazla etkilememekte; ancak, işten çıkarmalara neden olabilecek bir nitelik taşıyorsa sohbetlerin konusu haline gelebilmektedir. Rekabetçi yapısı gereği özel sektörde kişiler, kariyer gelişimlerinden bireysel olarak sorumluluk taşımalarından dolayı "iş tatmini" bireyler için daha fazla önem taşırken; kamuda "grup norm ve değerlerine aykırı davrananlar" hakkında konuşma daha yaygın olarak görülmektedir.

Katılımcılara kurum içerisinde dedikodu ve söylentilerin hangi olumsuz sonuçlara neden olduğunu düşündükleri sorulmuş ve yanıtlar Tablo-7 de verilmiştir.

Tablo 6: Dedikoduların Olumsuz Sonuçları

\begin{tabular}{lcc}
\hline & Özel & Kamu \\
\hline Çalışanların moralini bozması & \% 34 & $\mathbf{\% 3 8}$ \\
Çalışanlar üzerinde baskı oluşturması & $\% 23$ & $\% 16$ \\
Önemli çalışanların işten ayrılması & $\% 19$ & $\% 7$ \\
Çalışanlar arasında uyumun bozulması & $\mathbf{\% 3 0}$ & $\mathbf{\% 4 7}$ \\
Yönetim ve çalışanlar arasında güven kaybına neden olması & $\% 23$ & $\mathbf{\% 3 6}$ \\
Kurumda stres düzeyinin artması & $\% 22$ & $\% 34$ \\
Çalışanlar arasında güven kaybına yol açması & $\mathbf{\% 2 5}$ & $\% 30$ \\
Üretkenliğin azalması & $\% 17$ & $\% 20$ \\
Spekülasyonlara neden olması & $\% 17$ & $\% 15$ \\
Bireylerin itibarının zedelenmesi & $\% 18$ & $\% 12$ \\
İşgücü devir oranın artması & $\% 5$ & $\% 0$ \\
Yönetime karşı direnişe neden olması & $\% 7$ & $\% 6$ \\
\hline \hline
\end{tabular}

Teorik kısımda dedikoduların kuruma verdikleri zararların başında; çalışanların moralini bozması, güven ortamının kaybolması ve bunlara bağlı olarak ise üretkenliğin azalması olarak tanımlanmıştır. $\mathrm{Bu}$ açıdan bakıldığında elde edilen sonuçların, literatürde yer alan bilgilerle örtüştüğü rahatlıkla söylenebilmektedir. Katılımcılar, dedikodunun yarattığı olumsuz sonuçlar 
arasında "çalışanların moralinin bozulması", "çalışanlar arasında uyumun bozulması" ve "çalışanlar arasında güven kaybına yol açması" seçeneklerini daha çok tercih etmişlerdir.

Dedikodunun negatif etkileri zaten bilinen bir gerçektir. Özellikle bazı yöneticiler, dedikodu süreçlerine katılan çalışanları kurumdaki iyi şeyleri baltalamaya çalışan art niyetli kişiler olmakla suçlamaktadır. Ancak işin ilginç olan birçok yöneticinin çalışanlar arasında faaliyet gösteren FG'ye casuslar yerleştirerek konuşulanları öğrenmeye çalışmasıdır. Reyhanoğlu ve Akın (2016)'1n, toksik liderlik ile ilgili yaptıkları çalışmada, toksik liderlerin, dedikoduyu çalışanlardan bilgi edinmek için kullanabileceğine vurgu yapilmaktadır.

$\mathrm{Bu}$ kadar olumsuz sonuçlarına rağmen FG'nin toplum içerisinde en etkin çalışan mekanizmalardan biri olduğu düşünüldüğünde bazı işlevlere de sahip olması beklenmektedir. $\mathrm{Bu}$ açıdan yöneticilerin, FG'nin olumlu sonuçlarının gerçekten farkında olup olmadıklarını incelenmek istenmiştir. $\mathrm{Bu}$ nedenle katılımcılara dedikoduların olumlu etkisi olup olmadığ sorulmuştur (Tablo-8).

Tablo 7: Dedikodunun Olumlu Sonuçları

\begin{tabular}{lcc}
\hline & Özel & Kamu \\
\hline Yönetimin yapacağı değişikliklere karşı kendini hazırlama olanağı sağlaması & $\mathbf{\% 1 7}$ & $\mathbf{\% 3 0}$ \\
Duygusal ve psikolojik rahatlama sağlaması & $\mathbf{\% 1 1}$ & $\mathbf{\% 1 6}$ \\
Kişiler arasındaki ilişkileri geliştirmesi & $\% 9$ & $\% 12$ \\
Kişilerin kurallara aykırı bir şekilde yaptıkları işleri ortaya çıkarması & $\% 12$ & $\% 14$ \\
İşyeri ve diğer çalışanlar hakkında bilgi sahibi olunmasına olanak sağlaması & $\mathbf{\% 1 9}$ & $\mathbf{\% 1 4}$ \\
Belirsizliğin yarattığı gerilimi azaltması & $\mathbf{\% 1 0}$ & $\mathbf{\% 2 4}$ \\
Değişiklik kararının neden alındığını açıklaması & $\% 10$ & $\% 6$ \\
Çalışanların daha iyi değişim tahmini yapmasına yardımcı olması & $\% 12$ & $\% 12$ \\
Var olan süreçlerde yapplacak değişiklikler hakkında bilgi vermesi & $\% 9$ & $\% 15$ \\
Konuya ilişkin tam bir bilgilendirmenin ne zaman yapılacağına dair ön bilgi vermesi & $\% 6$ & $\% 5$ \\
Takım çalışması için ön bilgilerin edinilmesine yardımcı olması & $\% 8$ & $\% 7$ \\
& $\% 121$ & $\% 156$ \\
\hline \hline
\end{tabular}

Dedikodunun en önemli yararlarından birisi; bireyin çevresini anlamlandırabilmesi için gerekli verileri sağlamasıdır. Özellikle tahmin etmeye yönelik dedikodu türünde kişi, belirsizliğin yarattığı gerilimle baş etmek için diğer insanlarla müzakere etmekte ve olası ihtimallere karşı kendini hazırlamaya çalışmaktadır. Bu açıdan bakıldığında tüm katılımcılar, dedikoduların "yönetimin yapacă̆ düşünmektedir. Kamuda son dönemlerde yapılan önemli yapısal değişiklikler, kamu çalışanlarını "belirsizlik konusunda" daha hassas hale getirmektedir. Ayrıca dedikodunun "duygusal ve psikolojik rahatlama" sağladığı da katılımcılar tarafindan desteklenmektedir. Bunun dışında özel sektörde çalışan katılımcılar "dedikodunun, işyeri ve diğer çalışanlarla ilgili olarak bilgi toplanmasına yardımcı olduğunu" düşünmektedir.

Dedikodu türleri içerisinde "hayal borusu" ve "tahmin etmeye yönelik dedikodular" nispeten daha zararsız olan ve çalışanların işleri ile ilgili merak ve kontrol gereksinimlerinin doğal bir sonucudur. Buna karşın “öcü/kaygı” ve 
"agresif" dedikodu türleri daha çok başkalarını kaygılandırma ya da itibarsızlaştırma amacı gütmesinden dolayı kurum açısından çok daha olumsuz sonuçlar doğurmaktadır. Yöneticilerin, FG ile ilgili olarak tercih ettikleri stratejiler bu açıdan büyük bir önem taşımaktadır. Uygulamada en sıklıkla tercih edilen yöntemin FG'yi susturma ya da bastırmaya çalışmak olduğu görülmektedir. Ancak bu teknik, neredeyse hiçbir işe yaramayacağı en baştan belli olan stratejidir. Sonuçta, örgütsel iletişim mesai saatleri içerisinde kontrol edilebilse bile FG mesai saatlerinden sonra da faaliyetlerine hiç durmaksızın devam etmektedir. Başarısız olma ihtimalinin yüksekliğine karşı, yöneticilerin ilk olarak tercih ettikleri strateji olması ilginç bir durumdur. Araştırmaya katılan yöneticilere dedikodu ve söylentilerle mücadele için hangi stratejiyi tercih ettikleri sorulmuş ve yanıtları Tablo-9' da verilmiştir.

Tablo 8: Fisıltı Gazetesinin Yönetiminde Kullanılan Alternatifler

\begin{tabular}{lll}
\hline & Özel & Kamu \\
\hline Neden tam olarak bilgi verilmediğini ya da açıklanamayacağını açıklamak & $16 \%$ & $\mathbf{1 7 \%}$ \\
Dedikodu ya da söylentiyi resmi olarak yalanlama & $\mathbf{1 8 \%}$ & $15 \%$ \\
Dedikodu ya da söylentiyi kabul ederek açıklama yapmak & $\mathbf{1 9 \%}$ & $10 \%$ \\
FG'ni susturmak & $\mathbf{3 1 \%}$ & $\mathbf{3 3 \%}$ \\
Dedikodu ya da söylentilerle ilgili olarak yorumsuz kalmak & $2 \%$ & $5 \%$ \\
Örgüt içi iletişim kanallarının iki yönlü iletişime açık hale getirmek & $14 \%$ & $\mathbf{2 0 \%}$ \\
\hline \hline
\end{tabular}

Verilen cevaplardan hareketle hem kamu hem de özel sektör yöneticilerinin FG'yi susturulması/bastırılması gereken bir yap1 olarak değerlendirdikleri görülmektedir. Ayrıca dedikoduyu yalanlama ya da kabul etme de tercih edilen bir diğer stratejidir. Dedikodunun, kurumun hiyerarşik kanallarından bilgi akışının yetersiz ya da hiç olmaması durumunda arttığı düşünüldügünnde "örgüt içi iletişim kanallarının iki yönlü iletişime açık hale getirilmesi” büyük bir önem taşımasına rağmen özellikle özel sektör yöneticilerinin öncelikli tercihleri içerisinde yer almadığı görülmektedir.

\section{C. Örgütsel İletișim Aracı Olarak Fısıltı Gazetesi}

Bu bölümde Deepa ve Seth (2016) tarafından geçerliliği ve güvenirliliği ispatlanmış olan ölçekten yararlanılmıştır. Ölçeğe öncelikle faktör analizi uygulanmasına karar verilmiş ve ölçeğin faktör analizine uygun olup olmadığ1 ortaya koymak için Kaiser-Meyer Olkin (,769) ve Bartlett's (,000) testleri uygulanmıştır. Ölçeğin, faktör analizi için uygun olduğuna karar verilmiş ve faktör analizi yapılmıştır.

Tablo 9: Faktör Analizi

\begin{tabular}{|c|c|c|c|}
\hline & 1 & 2 & 3 \\
\hline FG, işletmede önemli bir iletişim aracıdır & & ,791 & \\
\hline Bir iletişim kanalı olarak dedikodu ve söylentileri dikkate alırım & & ,762 & \\
\hline FG, daha fazla iletişim isteyen çalışanlar için önemli bir ihtiyacı karşılar & &, 535 & \\
\hline FG'de yer alan bilgilerin, gerçeklik payı yüksektir & & ,482 & \\
\hline FG, yeni personelin iş çevresine alıştırarak sosyalleşmesin sağlar & 609 & & \\
\hline Doğru yönetilirse FG, iletişim kanallarının açık kalmasına yardımcı olur & 621 & & \\
\hline
\end{tabular}


FG, örgütsel sağlık, moral ve üretkenliğin bir göstergesi olarak kullanılabilir

FG, resmi iletişim kanalına göre daha hızlı ve tamamlayıcı bilgi sağlar

FG, üst yönetim karar vermeden önce çalışanların bilgi sunmasına firsat verir

Faktör analizi sonucunda dedikoduya ilişkin ifadelerin 3 faktör (etkili iletişim, ilave iletişim kanalı ve hızlı iletişim) altında toplandığı ve bu 3 faktörün toplam varyansların \%49'nu açıkladığı tespit edilmiştir. Birden fazla faktör yükü alan ve toplam faktör ağırlığı 0,45 'in altında olan bir ifade analizden çıkarılmış ve diğer ifadeler için Cronbach alfa değeri ,770 olarak hesaplanmıştır. Bu ifadelere ilişkin tanımlayıcı istatistikler Tablo-10'da verilmiştir.

Tablo 10: Tanımlayıc İstatistikler

\begin{tabular}{|c|c|c|c|}
\hline & & Ortala & Std. \\
\hline \multirow{4}{*}{ 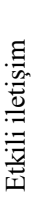 } & FG, işletmede önemli bir iletişim aracıdır & 3,52 & 1,397 \\
\hline & FG, daha fazla iletişim isteyen çalışanlar için önemli bir ihtiyacı karşılar & 3,14 & 1,266 \\
\hline & Bir iletişim kanalı olarak dedikodu ve söylentileri dikkate alırım & 3,05 & 1,287 \\
\hline & FG'de yer alan bilgilerin, gerçeklik payı yüksektir & 2,85 & 1,165 \\
\hline \multirow{6}{*}{ 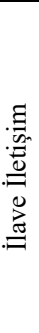 } & Resmi kanal kısıtlı/yavaş çalıştığı durumlarda önemli olaylar FG ile aktarılabilir & 3,69 & 1,201 \\
\hline & Kurumda hiyerarşik kademeler arttıkça FG daha etkin olarak çalışmaya başlar & 3,31 & 1,276 \\
\hline & FG, örgütsel sağlık, moral ve üretkenliğin bir göstergesi olarak kullanılabilir & 3,30 & 1,218 \\
\hline & Doğru yönetilirse FG, iletişim kanallarının açık kalmasına yardımcı olur & 3,23 & 1,206 \\
\hline & FG'yi, yok etmeye çalışmak yerine etkili bir şekilde kullanmak gerekir & 3,19 & 1,216 \\
\hline & FG, yeni personelin iş çevresine alıştırarak sosyalleşmesine yardımcı olur & 3,11 & 1,258 \\
\hline \multirow{4}{*}{ 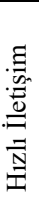 } & FG’nin zamanlaması, çalışanların örgütsel kararlara katılmasına yardımcı olur. & 3,18 & 1,324 \\
\hline & FG, resmi iletişim kanalına göre daha hızlı ve tamamlayıcı bilgi sağlar & 3,12 & 1,142 \\
\hline & FG, üst yönetim karar vermeden önce çalışanların bilgi sunmasına firsat verir & 2,99 & 1,234 \\
\hline & FG yardımıyla bilgiler daha hızlı yayılır & 2,88 & 1,216 \\
\hline
\end{tabular}

Tablo-10 incelendiğinde tüm faktörler açısından ortalamaların oldukça düşük olduğu görülmektedir. Yöneticilere, "dedikodunun ne gibi olumlu sonuçları olduğunu düşünüyorsunuz?" diye sorulduğunda tercih ettikleri seçenekler literatürdeki bilgilere neredeyse birebir karşılık gelmekte iken; "kesinlikle katıliyorum, katılıyorum, kararsızım, katılmıyorum ve kesinlikle katılmıorum" şeklinde ifadelerden birini seçmeleri istendiğinde "katılmıyorum" ve "kesinlikle katılmıyorum" ifadelerinin çok daha baskın olduğu görülmektedir. İfadelere 
katılım düzeylerinin çok düşük olması, yöneticilerin dedikoduya itibar eden bir yönetici algısı yaratmaktan çekinmesinden kaynaklanabilir. Tüm ifadeler içerisinde en yüksek ortalama "Resmi kanal kısıtlı/yavaş çalıştığı durumlarda önemli olaylar FG ile aktarılabilir" ifadesi $(3,69)$ iken en düşük ortalamaya sahip olan ifade ise "FG'de yer alan bilgilerin, gerçeklik payı yüksektir" ifadesidir $(2,89)$. Katılımcılar resmi iletişim kanallarının yavaş çalıştığı dönemlerde, bireylerin bilgi gereksinimlerinin FG aracılığıyla karşılanabildiğini kabul etmekte ancak bu bilgilerin doğruluğundan şüphe etmektedir.

\section{Yöneticilerin Demografik Özellikleri ile Fısıltı Gazetesine Bakış Açıları Arasındaki İlişskiler}

Yöneticilerin demografik özellikleri ile FG'ne bakış açıları arasında ilişki olacağ düşünüldüğünden demografi faktörler açısından incelemeler yapilmıştır. Söz konusu analizlerde, One Way Anova ve Bağımsız Örneklem T-Testi kullanılmıştır.

Yaş; değişkeni açısından sadece "etkili iletişim" boyutu açısından anlamlı bir farklılık $($ sig=0,030) tespit edilmiştir. Söz konusu farklılık 46-50 yaş arası grup, 26-30 ve 31-35 yaş grupları arasındadır. Yaş ilerledikçe insan ilişkilerine olan bakış açısı farklılaşması bilinen bir durum olduğundan genç yöneticiler ve kıdemli yöneticiler arasındaki farklılaşma oldukça doğaldır.

Cinsiyet; açısından "etkili iletişim" boyutu açısından anlamlı farklılık ( $\operatorname{sig}=0,01)$ tespit edilmiş olup bu farklılık kadınlardan kaynaklanmaktadır. Kadın yöneticiler, dedikodunun etkili bir iletişim yöntemi olduğunu düşünmektedir.

Deneyim süresi açısından ise "etkili iletişim" $(\operatorname{sig}=0,00)$ ve "hızlı iletişim" (sig=0,021) boyutları açısından istatistiki olarak anlamlı bir farklılık söz konusudur. Etkili iletişim boyutu açısından farklılık deneyim süresi 25 yıldan fazla olan katılımcılar ile deneyim süresi "1 yıldan az", "4-6 yıl arası" ve "7-9 yıl arası" olan gruplar arasındadır.

Çalışan sayısı bakımından gruplar arasında istatistiki olarak anlamlı bir farkl11ık tespit edilememiştir.

Faaliyet gösterdiği kurum (kamu/özel sektör) açısından bakıldığında ise üç boyut (etkili iletişim $=0,002$; ilave iletişim $=0,01$; hılı iletişim $=0,01$ ) açısından da istatistiki olarak anlamlı bir farklılık olduğu tespit edilmiştir. Her üç faktör açısından da farklılık özel sektörden kaynaklanmaktadır.

\section{TARTIŞMA VE SONUÇ}

FG, bilgilerin dedikodu ve söylentiler yoluyla iletilmesine olanak sağlayan informal bir iletişim kanalıdır. Çalışanlara sosyal etkileşim ve dayanışma olanağı sağlayarak, sosyal örgütün korunmasına ve gelişmesine yardımcı olmaktadır. Ancak bunun yanı sıra özellikle belirsizliğin arttığ1 dönemlerde yanlış haberlerin yayılmasına neden olarak çalışanlar arasında kaygı ve endişeleri de arttırabilmektedir.

Bu çalışmada kamu ve özel sektörde görev yapan 315 yöneticiyle anket yapılmıştır. Katılımcıların sadece yaklaşık \%27'si 6 aydan daha fazla bir süredir dedikodu duymadıklarını ifade etmiştir. Diğer katılımcılar; her gün, haftada ya da 
en geç ay bir dedikodu duyduklarını ifade etmişlerdir. Bu durum, FG'nin sürekli aktif olarak çalışan bir kanal olduğunu göstermektedir.

Katılımcıların \%25'i, dedikoduların her zaman yanlış bilgilerin yayılmasına neden olduğunu düşünmektedir. Diğer katılımcılar ise söyleyen kişinin güvenilirliğine veya niyetine bağlı olarak dedikodunun doğru olabileceğini düşünmektedir. $\mathrm{Bu}$ durum, yöneticilerin FG'den gelen bilgilere karşı duyarlı olduğunu göstermektedir. Eroğlu (2005)' da benzer şekilde yöneticilerin kurum içerisinde dedikodu dikkate aldıklarını, dedikodu ve söylentilerin arttığı zamanları tespit ettiklerini, kurum yararlarına olan dedikodulardan yararlandıklarını tespit etmiştir. Hafen (2004), dedikodu ve örgütsel vatandaşlik davranışı (ÖDV) arasındaki ilişkiyi incelediği çalışmasında dedikoduyu "işyerinde sapma davranışı" olarak tanımlanmıştır. İkramiye dağıtılacağına dair söylentiyi örgütsel ÖDV'le ilişkilendirilirken; yöneticinin hayırseverliğinin aktarıldığı bir dedikoduyu ise bireysel ÖDV olarak kabul etmiştir. Buna karşın yöneticinin bir çalışanla ilişkisi olduğuna dair bir söylentiyi “işyerinde sapma davranışı” olarak tanımlamıştır. Ayrıca Erol ve Akyüz (2015), sağlık sektöründe yaptıkları araştırmada dedikodunun örgütsel işlevleri ve yararlarına ilişkin ifadelerin çalışanlar tarafından kabul gördüğünü ifade etmiş ve dedikodunun olumlu ya da olumsuz sonuçlarını belirleyen en önemli unsurun yönetimin tavrı olduğuna dikkat çekmişlerdir.

Dedikoduların ana temasını genellikle iş ortamı ve maddi konular oluşturmaktadır. Katılımcılar, çalışanların genellikle "sohbet/eğlenme", "merak duygusunu giderme" veya "daha yüksek güç ve statü elde etme/başkalarının itibarını zedeleme” amacıyla dedikodu yaptığını düşünmektedir.

Katılımcılar FG, dedikodunun en olumsuz sonuçları arasında "çalışanların moralinin bozulması" ve "çalışanlar arasında uyumun bozulması" olduğunu düşünmektedir. Gouveia, Vuuren ve Crafford (2005) yaptıkları çalışmada dedikoduyu; özel, doğru/yanlış, yanlış anlaşılabilen, abartılan, pozitif/negatif, iş/özel yaşamla ilgili, travmatik, skandal, işle doğrudan ilgili olmayan ancak çalışanları etkileyen bilgilerin yayılımı olarak tanımlanmaktadır. Dedikodunun olumsuz sonuçlarının, orman yangını gibi hızla yayılarak yanlış kulaklara ulaşmasından ya da zor, sıkıntılı ve stresli durumlar oluşturmasından kaynaklandığı ifade etmişlerdir. $\mathrm{Bu}$ açıdan bakıldığında çalışmada elde edilen sonuçların literatürde elde edilen diğer sonuçlarla tutarlı olduğu görülmektedir.

Katılımcılar dedikodunun özellikle belirsizliğin arttı̆̆ı değişim zamanlarında çalışanların kendilerini hazırlama olanağ düşünülmektedir. Heacthcote ve Dowson (2008)' ın örgütsel değişim sürecinde ön saflarda çalışan personel arasındaki iletişim ve söylenti üzerine yaptıkları araştırmada da değişim sürecinde iletişimin kalitesinin niteliğinin ve niceliğinin önemli olduğu vurgulanmıştır. Heathcote ve Dowson özellikle örgütsel değişim dönemlerinde dedikoduların arttığını ifade etmiştir.

Dedikodunun pozitif duygusal ve psikolojik bir rahatlama sağladiğı da katılımcilar tarafından desteklenmektedir. Bu bulgular, Waddington (2005)'un çalışmasında ulaştığı dedikodunun "gevşeme/kahkaha atma" gibi pozitif çıktılara 
neden olabileceği ya da önemli sorunların çözüm bulunabilmesi için "havayı yumuşatma" özelliğinin olduğuna dair bulgular ile örtüşmektedir. Bunun yanı sıra stresle mücadele yöntemlerinden duygusal odaklı başa çıkma ve problem odaklı başa çıkma yöntemleri yararlı stratejiler olup dedikodunun burada rol oynayabileceğini ifade etmiştir. Duyguları ifade etmenin yanı sıra kişiler arası ilişkilerin desteklenmesine de yardımcı olmaktadır. Bu açıdan literatürde yer alan dedikodunun işlevlerini ampirik olarak desteklemektedir. Ayrıca çalışmada hemşirelerin, manipülatör ya da baskıcı bir özellik taşıyan hastalara maruz kaldıkları da ifade edilmiştir. Bu tür hastalar; zor ya da popüler olmayan kişiler olarak değerlendirilerek dedikodu konusu olabilmektedir.

Katılımcıların demografik özellikleri de FG'ye bakış açılarını etkilemektedir. FG, "etkili iletişim" boyutu açısından yaş, cinsiyet ve deneyim süresi bakımından katılımcılar arasında istatistiki olarak anlamlı farklılıklar tespit edilmiştir. Katılımcıların çalıştı̆̆ kurum açısından "etkili iletişim", "ilave iletişim kanalı" ve "hızlı iletişim" boyutları arasında istatistiki olarak anlamlı bir farklılık tespit edilmiştir.

Gerek kamu gerekse özel sektör yöneticileri, öncelikle FG'yle ilgili olarak öncelikle "susturma/bastırma" stratejisini tercih etmektedir. Ancak bu yapının yok edilmesi ya da baskı altına alınması ise neredeyse olanaksızdır. Bir yerde engellense diğer yerde tekrar ortaya çıkabilmektedir. Bu nedenle en doğrusu, FG'yi yok etmeye çalışmak yerine onu yönetmektir. FG'nin çıkarları ile örgütün amaçlarını bütünleştirmek isteyen yönetici; onu dinlemeli ve onun dinamikleri üzerine çalışmalıdır. Ayrıca FG'nin liderinin kim olduğunu, nasıl bir işleyişe sahip olduğunu ve bilginin nasıl taşındığını anlamak zorundadır.

\section{KAYNAKÇA}

Baker, J. S., \& Jones, M. A. (1996, Spring). The Poison Grapevine: How Destructive Are Gossip and Rumor in the Workplace. Human Resource Development Quarterly, 7(1), s. 75-88.

Beersma, B., \& Kleef, A. V. (2011). How the Grapevine Keeps You in Line: Gossip Increases Contributions to the Group. Social Psychological and Personality Science, 2(6), s. 642649. doi:10.1177/1948550611405073

Bhasin, S. (2013). Rumours Galore... to Gossiping No More !!! Human Capital, 18-24.

Danış, M. S. (2015). Dedikodunun Sosyolojisi. Konya: Selçuk Üniversitesi Sosyal Bilimler Enstitüsü Yayınlanmamış Yükseklisans Tezi.

Davis, K. (1953, September-October). Management Communication and the Grapevine. Harvard Business Review, 31(5), s. 43-49.

Davis, K. (1969). Grapevine Communication Among Lower and Middle Managers. Personel Journal.

Davis, K. (1973, October). The Care and Cultivation of the Corporate Grapevine. Management Review, 62(10), s. 53-56.

Deepa, S., \& Seth, M. (2016, April). Can Organizational Grapevine be Beneficial? An Exploratory Study in Indian Context. English for Specisific Purposes World, 19(49).

Dingfelder, S. F. (2006, April). Learned it through the Grapevine. 02 19, 2018 tarihinde APA Monitor on Psychology: http://www.apa.org/monitor/apr06/grapevine.aspx adresinden alınd1

Dodig-Crnkovic, G., \& Anokhina, M. (2008). Workplace Gossip and Rumor: The Information Ethics Perspective. In Proceeding of the Tenth International Conference ETHICOMP. 
Dunbar, R. (1997). Grooming, Gossip, and the Evolutaion of Language. USA, London: Harvard University Press.

Elder, D., \& Enke, J. L. (1991, August). The Structure of Gossip: Opportunities and Constraints on Collective Expression among Adolescents. American Sociological Review, 56(4), s. 494508.

Eroğlu, E. (2005). Yöneticilerin Dedikodu ve Söylentiye Yönelik Davranış Biçimlerinin Belirlenmesi: Arfor Taşıma Hizmetleri A.Ş.'de Bir Uygulama. Kırgızistan-Türkiye Manas Üniversitesi Sosyal Bilimler Dergisi, 7(13), s. 203-219.

Erol, Y., \& Akyüz, M. (2015). Dünyanın En Eski Medyası: Dedikodunun Örgüt Düzeylerindeki İşlevleri ve Algılanışı: Sağlık Örgütlerinde Bir Alan Araştırması. Journal of World of Turks, 7(2), s. 149-168.

Feinberg, M., Willer, R., \& Schultz, M. (2014). Gossip and OStracism Promote Cooperation in Groups. Psychological Science, 25(3), s. 656-664.

Gholipout, A., Kozekanan, S. F., \& Zehtabi, M. (2011). Utilizing Gossip as a Strategy to Construct Organizational Reality. Business Strategies Series, 12(2), s. 56-62. doi:10.1108/17515631111114859

Gouveia, C. D., Vuuren, L. V., \& Crafford, A. (2005). Towards a Typology of Gossip in the Workplace. SA Journal of Human Resource Management, 3(2), s. 56-68. doi: https://doi.org/10.4102/sajhrm.v3i2.68

Hafen, S. (2004). Organizational Gossip: A Revolving Door of Regulation and Resistance. Southern Communication Journal, 69(3), s. 223-240. doi:10.1080/10417940409373294

Hallett, T., Harger, B., \& Eder, D. (2009). Gossip at Work: Unsanctioned Evaluative Talk in Formal School Meettings. Journal of Contemporary Ethnography, 38(5), 584-618. doi: $10.1177 / 0891241609342117$

Harari, Y. N. (2012). Hayvanlardan Tanrllara Sapiens: Insan Türünün Kısa Bir Tarihi. (E. Genç, Çev.) İstanbul: Kolektif Yayınları.

Heathcote, E., \& Dawson, S. (2008). Have You Heard? The Role of Rumour During Organisational Change Processed. International Journal of Knowledge, Culture and Change Management, 8(2), s. 273-283.

Kanber, L. K. (2015, Mayıs-Haziran). Sırrın Evrimsel Yükü. Psikeart(39).

Kapferer, J.-N. (1992). Dedikodu ve Söylenti: Dünyanın En Eski Medyası. (I. Gürbüz, Çev.) İstanbul: İletişim Yayınları.

Manaf, M. M., Ghani, E. K., \& Jais, I. M. (2013). Factors Influencing the Conception of Rumours in Workplace. Journal of Arts and Humanities, 2(6), s. 50-63.

Michelson, G., \& Mouly, S. (2000). Rumour and Gossip in Organizations: A Conceptual Study. Management Decision, 38(5), 339-346. doi:http://dx.doi.org/10.1108/00251740010340508

Michelson, G., \& Mouly, V. S. (2002). You Didn't Hear if From Us But....': Toward and Understanding of Romour and Gossip in Organizations. Australian Journal of Management, 27(Special Issue), s. 57-68.

Mishra, J. (1990). Managing the Grapevine. Public Personnel Management, 19(2), s. 213-229. doi:10.1177\%2F009102609001900209

Nicoll, D. C. (1994). Acknowledge and Use Your Grapevine. Management Decision, 32(6), s. 2530. doi:https://doi.org/10.1108/00251749410065097

Noon, M., \& Delbridge, R. (1993). News from Behinde My Hand: Gossip in Organizations. Organization Studies, 14(1), s. 23-37. doi: 10.1177\%2F017084069301400103

Reyhanoğlu, M., \& Akın, Ö. (2016). Toksik Liderlik Örgütsel Sağlığı Olumsuz Yönde Tetikler mi? Insan ve Toplum Bilimleri Araştırmaları Dergisi, 5(3), s. 442-459.

Ribeiro, V., \& Blakeley, J. A. (1995). The Proactive Management of Rumor and Gossip. JONA, 25(6), s. 43-51. doi:https://doi.org/10.1300/J075v23n02_07

Rivero, O. (2013). Rumors in the Workplace Affecting Organizational Change. Global Journal of Management and Business Research Administration and Management, 13(12).

Rosnow, R. L. (1980). Psychology of Rumour Reconsidered. Psychological Bulletin, 87(3), s. 578591. 
Waddington, K. (2005). Behind Closed Doors-the Role of Gossip in the Emotinal Labour of Nursing Work. Int. J. Work Organisation and Emotion, 1(1), s. 35-48.

\section{SUMMARY}

The grapevine is an informal communication channel that allows information to be transmitted through gossip and rumors. It provides employees with the opportunity for social interaction and solidarity, helping to protect and develop a social organization. In this study, a survey was conducted with 315 managers working in the public and private sectors. Approximately $75 \%$ of respondents stated that they heard gossip every day, week or month at the latest. This shows that the grapevine is a channel that is constantly and actively working. $25 \%$ of the respondents think that rumors cause false information to spread. Other participants think that the rumor may be true, depending on the credibility or intentions of the speaker. This indicates that managers are sensitive to information from the grapevine. Participants think that employees generally are gossiping to "chat/have fun", "satisfy one's curiosity", or "get higher power and status" and "damage the reputation of others". The negative effects of the gossip on the corporation are "deterioration of morale in employees" and "deterioration of harmony among employees". Gossip helps employees to understand their surroundings and prepare themselves during periods of increasing uncertainty. In spite of this, gossip helps the employees to understand their surroundings and prepare themselves during periods of increasing uncertainty. Participants also state that gossip provides psychological/emotional relief. The demographic characteristics of the participants also influence their views on the grapevine. In terms of "effective communication" dimension, statistically significant differences were found between participants in terms of age, gender, and experience. Statistically significant differences were found between public and private sector managers in terms of "effective communication", "additional communication" and "rapid communication" dimensions. Both public and private sector managers prefer primarily the strategy of "suppressing" or "destroying" the whispering journal. However, it is almost impossible to destroy or suppress this structure. If it is suppressed in one place, it appears again in the other place. For this reason, it is best to manage the grapevine instead of trying to destroy it. The manager who wants to integrate the interests of the grapevine with the goals of the organization; he must understand and comprehend its dynamics. He also has to understand who the leader of the grapevine is, how it has a functioning and how the information is transmitted. 